\title{
Reinterpreting Ramayana: The (Re)Production of the Meanings of Power in "Ramayana", an East Javanese Shadow Puppet Performance Text
}

\author{
Basuki, R. ${ }^{1}$ and Setiawan, D. ${ }^{2}$ \\ ${ }^{1,2}$ English Department, Faculty of Letters, Petra Christian University, Siwalankerto 121-131, Surabaya 60236, \\ East Java, INDONESIA \\ E-mails: rbasuki@peter.petra.ac.id; dewey@peter.petra.ac.id
}

\begin{abstract}
In this article we discuss the meanings of power that are produced/reproduced in an East Javanese shadow puppet show entitled Ramayana by Ki Sinarto. In Foucauldian perspective, the meanings of power are constantly intertwined with other issues, and in Ki Sinarto's Ramayana they are closely related to the state, revelation/women, family, and people. Despite the puppeteer's efforts in doing a 'subversive interpretation' of Ramayana, the Javanese concept of power still 'overpowers' his discourse. Addressing the contemporary Indonesian state, Ki Sinarto is propagating the concept of Javanese power from the late Mataram kingdom. He also proposes that women can have a legitimizing power as the bearers of revelation, but the discourse of women as distractors to men's career still surfaces. Ki Sinarto further pictures the main conflict of Ramayana as a dispute of an aristocratic family instead of woman. Finally, the relations between Javanese people and their leaders are not necessarily straightforward and linear.
\end{abstract}

Key words: Javanese shadow puppet, Ramayana, power relations, state, women, family, people.

\section{INTRODUCTION: SETTING THE CONTEXT}

As one of the styles in Javanese shadow puppet theatre in general, East Javanese shadow puppet style is not a single, unified one. Instead, it consists of many sub-styles pertaining to different areas of its development in East Java. Kayam (2001) noted that the sub-styles of East Javanese Shadow Puppet can be grouped into that of Lamongan, Porongan (which includes the areas of Japanan, Sidoarjo, Surabaya and Gresik), Mojokertoan, Jombangan, and Malangan $^{i}$ (p. 63). Lamongan sub-style is different from other styles especially in terms of language and, sometimes, music. The language of Lamongan sub-style is more like that of Mataraman ${ }^{i i}$ style. Its music, on the other hand, is more like a mix of styles between Porongan and Mataraman. This is perhaps owing to the fact that geographically, as a county Lamongan is at the boundary between the tlatah (cultural areas) of Arek and Mataraman iii. Lamongan county, which is located in the northern part of Arek cultural area shares boundaries with the county of Bojonegoro in the west, which culturally belongs to Mataraman area. In terms of music, Lamongan sub-style is more like that of Porongan. While Mataraman, especially Surakarta, style consists of three pathets ${ }^{i v}$ (nem, sanga, and manyura), Lamongan sub-style, such as East Javanese styles in general, has four pathets (wolu, sedasa, sanga, and serang) with more jejer ${ }^{v}$ (p. 86).

In this paper we discuss an audio-recorded text of Lamongan sub-style entitled Ramayana by Ki Sinarto ${ }^{\mathrm{vi}}$. When we first listened to its tape-recorded text, we mistook it for a Mataraman style because its music sounded like that of the dominant group. Only when one of us (Basuki) asked Ki Sinarto himself were we convinced that the style was East Javanese. After we listened more to the tape, we could see that the music style was different from that of Mataraman. However, our categorical mistake was also due to the fact that Ki Sinarto made a sanggit (composition) which was unusual at the text. For the music, Ki Sinarto, who holds a degree in gamelan, deliberately incorporated Mataraman (western) and East Javanese (eastern) styles. In terms of story, his composition can be said to be 'subversive' because Ki Sinarto made Ravana a 'hero' in the show, unlike the conventional composition in which Ravana is characterized as a 'villain'.

Ki Sinarto made a subversive interpretation by characterizing Sita, who is the incarnation of Goddess Vedavati (goddess of prosperity), as the son of Ravana. Sita is dumped by Vibhishana as an infant for fear of Ravana's intention of marrying her own daughter to get "prosperity revelation". Ravana keeps on looking for his daughter, until finally he gets informed by Togog, his servant, who knows what has actually happened to his baby girl. When Ravana finally meets Sita, she has become the wife of Rama. Ravana discovers Sita when she is left alone in the jungle by Rama, who is at that moment disappointed for not being crowned king of Ayodhya. Ravana finally takes Sita to Lanka. To get his wife back, Rama attacks Lanka, not knowing that he is actually attacking his father-in-law. After 
the death of several knights including Kumbhakarna, the brother of Ravana, Ravana and Rama finally meets face to face. In this meeting Ravana blames Rama for the chaos since, as the incarnation of Vishnu, he cannot see the truth. The story ends when Ravana leaves Rama alone to ponder upon Ravana's words.

By using this sanggit, Ki Sinarto has moved away from the conventional story which tends to be interpreted melodramatically by some puppeteers. Rama-Ravana rivalry is usually interpreted as good versus evil, and Ravana is often interpreted as the incarnation of evil. In Ki Sinarto's sanggit, each character has its own reasonable motives and no character is completely villainous. Ki Sinarto's composition is "scientifically" reasonable because, as he says himself in the text, being a well-read puppeteer he bases his composition on a research. In fact, there are sources which show that Sita is the daughter of Ravana, for example in Purwacarita (Eksiklopedia Wayang Purwa, 1991, pp. 480482). In these sources, however, there is no exploration in making Ravana a hero like that done by Ki Sinarto. As a puppeteer who has a Master's degree (he was waiting for his Master's degree while doing this show), and holds a managerial position in Taman Budaya Jawa Timur (East Java Cultural Park), he has an intellectual authority to make his own composition, however unpopular it may be.

As it is indicated in the title, we will discuss Ramayana by Ki Sinarto with some limitations. First, we limit the text, context and subjects to the tape-recording. Second, we will discuss only the meanings of power that are produced/ reproduced in the text. Third, our discussion on the meanings of power is in the light of Foucauldian power relations. It should be emphasized that power relations in the production/reproduction of meanings is a discursive process; therefore, the discussion of the meanings is discursive as well. This fact refers to the idea "that the relations of power are intertwined with other kinds of relations (production, kinship, family, sexuality) in which they play both the roles of conditioning and being conditioned" (Foucault, 2002, p. 175).

It should also be emphasized that the text of this recording contains both context and subjects of the show. Unlike film as a text, for instance, a recorded text of Javanese shadow puppet performance reveals not only shadow puppet characters but also the puppeteer, musicians, and even the audience. The text is an audio-record of the performance by Ki Sinarto in 2006 at Balai Pemuda (Surabaya Youth Center), a property owned by the Surabaya city government for certain activities, including art. The artists involved are elite (especially traditional) artists in the city of Surabaya in particular, and East Java in general. Even though, of course, there are 'layman' spectators from outside the group of artists in Surabaya, a lot of Surabaya artists are in the audience, so oftentimes there are spontaneous dialogues between the puppeteer, who uses the voice of puppet characters or his own, and the audience. Thus, it can be said that the puppet performance itself is discursive, unlike Aristotelian theatre, in terms of text, context, and subjects.

\section{THE MEANINGS OF POWER IN KI SINARTO'S RAMAYANA}

We came across the audio-recorded text of Ramayana by $\mathrm{Ki}$ Sinarto when one of us (Basuki) was collecting data for his research on identity and power. In this research, he planned to scrutinize how identity is connected with power relations in East Javanese shadow puppet performances. To his surprise, when he first listened to the recording of this show, he found out that the meanings of power itself were often (re)produced. Therefore, it may be regarded that the meanings of power are most prominent in this show. From the beginning to the end of the show, discussions on power happen continuously. Furthermore, the discussions of power in this text happen in three levels: the story (main text) which shows the puppet characters as subjects, the stage (extended text) which includes characters in the story as well as the dalang (puppeteer), panjak (musician), and sindhen (singer) as subjects, and the context which includes subjects outside the stage: the audience and the intended audience $^{\text {vii }}$. In discussing the meanings of power in the text, we will explore the following topics: 1) power and the state, 2) power, wahyu (revelation), and women, 3) power and the family, and 4) power and the people.

\section{Power and the State}

The issues of power surfaces in the text when God Narada comes down from heaven to settle a dispute between Dashamuka and Danaraja (Kubera), his stepbrother. This dispute occurs because Danaraja is attempting to kill Vishrava, his father. Danaraja has asked Vishrava to propose Kaikesi for him but, instead, Vishrava marries her himself. In anger, Danaraja invades Lanka to capture Vishrava. Dashamuka, son of Kaikesi and Vishrava, defends his father and his country from Danaraja's invasion. God Narada descends from heaven to stop the dispute and blames Danaraja whom he considers unable to accept his 'destiny'. Danaraja defends himself by saying that he wants to kill his father because his father has polluted his country, Lokapala, by act of treachery. As a matter of fact, according to Narada, Kaikesi has been destined to be the wife of Vishrava, so Vishrava has not done any mistake. While advising Danaraja, Narada says: "Ratu ora bisa mangreh karo awake dhewe kok ndadak dandan-dandan negara" [Being unable to control himself, a king should not try to build the country] (Sinarto, 2006, Cass. 3). Narada further says that a king must be able to 'regulate' himself and accept the conditions destined to him. Only then could he rule the country. The mastery of the country must be preceded by the mastery of the self. Furthermore, Narada says:

Ngono kok dadekke ratu. Ratu karo dulure geger ae. Sing siji ngedekna partai . . . Kamongko biyen ya mbelani. Bareng saiki akeh koncone malah nglawan. Kamangka durung karuan menang. (Cass. 3)

[So why become a ruler. Being a king, yet keeps on fighting with his own brother. One of them founded a party. . . Yet the other supported, at first. Right now when he gets a lot of allies, he intends to compete. Though he won't necessarily win] (Cass. 3) 
From the quotation above, we can see that a king should be able to restrain himself to avoid conflicts. Such teaching is common place in shadow puppet performances, especially in scenes when a god or guru meets the 'satria ${ }^{\text {viii's. }}$

However, from the same passage we also see that the context has shifted from shadow puppet's setting to that of the present, Indonesia or East Java, contexts ${ }^{\mathrm{ix}}$. Ki Sinarto is reproducing the concept of Javanese power to address the contemporary context. By mentioning the word parties, for instance, Ki Sinarto shifts the passage to the political life of the present Indonesia/East Java since there should never be a party in Ramayana context itself. Thus, to Ki Sinarto, the present leaders/government officials need to have an understanding of the concept of power developed since Mataram period (1570-1755), in which a leader/king should be able to control himself and must comply with the given destiny from heaven (this is associated with the wahyu/revelation, which will be discussed later). What is happening in Indonesia at the moment is due to the inability of the leaders to behave according to the values of Javanese leadership. Ki Sinarto does not only relate the concept of power to top leaders like kings or presidents but also power in any position, even though he does it in a dialogue between God Narada with Ravana. "Wong yen arep nanpa kanugrahan kuwi ya rada lara. Dipitenah karo kanca, disara-sara karo kepala kuwi wis biasa ngono. Tenan kuwi" (Cass. 3). [When somebody is receiving a blessing, he must suffer first. Being vilified by friends, hurt by superiors is common, you know. That is true] (Cass. 3). Narada says it to Ravana who is in pain because he is tied and dragged with a chariot by Danaraja. Finally, Ravana is healed and Danaraja is taken to heaven by Narada. Danaraja is made god of wealth, and the State of Lokapala is given to Ravana. Ravana, who has lost the fight when he is defending his father and his country, becomes the ruler of Lokapala, replacing Danaraja.

It is obvious that in the dialogue Ki Sinarto is also talking about power or position in the present, day to day, context. Interestingly, in this context, the contemporary state government is not necessarily different from that of the kingdom in the past. Power is a gift (from the Almighty), and it is acquired with difficulty through competition with friends and pressure from superiors. So, power is a property that should be acquired with efforts. We can see at this point that power in Javanese shadow puppet world is considered as 'something' that can be obtained as discussed by Moedjanto (1987) or Anderson (1990). To Anderson,

Javanese power is concrete. This is the first and foremost formulation of Javanese political thought. Power is something real, it does not depend on those who may use it. Power is not a theoretical postulate but an existential reality (p. 47)

However, it should be understood that such power is that contemplated 'by the Javanese [ruling class]', which continues to be (re)produced since the antiquity. In other words, Anderson simply 'captures' the concept of Javanese power as it is believed and practiced by the Javanese to build and sustain the monarchy (Moedjanto, 1987, pp. 101117 ) in pre-colonial to colonial time (Moedjanto's research) and in post-colonial, especially in the New Order, period (Anderson's research).

In fact, in our opinion, Javanese concept of power is the 'dream' of the ruling elite to build the country/kingdom. The 'dream' has never been materialized because of the struggle of power among the elite themselves. However, the 'dream' always lives in the 'collective consciousness' of Javanese community so that it is (re)produced continuously. The dream is not only in its broadest sense in the context of the State, but also in specific forms such as in any given power space (managerial post) in state offices. Conflicts among colleagues and between superiors-subordinates are represented, implicitly or otherwise, in Ramayana by Ki Sinarto. However, in Foucauldian perspective, these conflicts merely show power relations which commonly happen in the society so that power does not always have its negative or 'reductive' meanings (Foucault, 2002, p. 173). Referring back to the text, Ki Sinarto suggests that colleagues are both friends and rivals who may trigger competition to succeed, although sometimes the competetion may be fierce and brutish. Superior-subordinate relations are inevitable in an organization to make the duties and responsibilities clear. Accordingly, the statement by Sumali (king of Lanka, Ravana's grandfather) that "being a king is burdensome" (Sinarto, 2006, Cass. 3) should not only be understood in the context of the state of Lanka, but also in the context of the current state, Indonesia. This statement also applies to the head of Balai Pemuda (Surabaya Surabaya Youth Center), a few spectators who are also heads of their own offices, the puppeteer himself who is the head of the Administration Office at Taman Budaya Jawa Timur (East Java Cultural Park), and every head who should undergo power relations with superiors, colleagues or subordinates.

It should be noted, however, that power relations within the context of bureaucracy in Java in general, from this text, still has not moved away from the bureaucracy of the (late) Mataram kingdom. Ki Sinarto only (re)produces his knowledge of the concept of Javanese power and culture, and his knowledge cannot be separated from the existing power relations. From this show, it is seen that even though Surabaya is far from the 'remnants' of the late Mataram kingdom, the dream of having a democratic state system is still hindered by the Javanese feudalistic concept of power.

It should also be noted that Ki Sinarto is also trying to criticize the concept of national defense which, in the world of puppet characters, is often drawn from the character of Kumbhakarna. The general concept of defending the country as seen in the life of Kumbhakarna is that as a warrior; Kumbhakarna decides to join the war because he wants to defend his country, Lanka, not his evil brother, Ravana. Kumbhakarna is considered exemplary because as a warrior, he defends the interests of the state instead of that of the leaders, especially if the leader has done wrong. For $\mathrm{Ki}$ Sinarto, however, Kumbhakarna dies in vain because he does not know "sejatining lelakon" [the real truth] (Sinarto, 2006, Cass. 7). Therefore, Kumbhakarna only "nubruk bentus sakarepe dhewe" [acts recklessly] (Cass. 7) on the battlefield. He does not understand that the biggest mistake is not on Ravana, but rather on Vibhishana, his other 
brother, who has made false interpretation of Ravana's statements. Kumbhakarna, for Ki Sinarto, does not have to die if he knows the seat of the problem. Finally, Ki Sinarto's (re)production of the concept of power as such is related to his experience as a civil servant over the years, in addition to his understanding of Javanese philosophy as a puppeteer. Despite his efforts to do a 'subversive interpretation' of Ramayana, Javanese values and the bureaucratic system of Indonesia are still far more "powerful" than himself, so his work is not free from the power of the ideology that operates over him.

\section{Power, Revelation and Women}

The meaning of power in Ki Sinarto's Ramayana is also inseparable from the concept of 'wahyu lan wanita' [revelation and women]. In the shadow puppet world, Wahyu occupies a central position as the legitimation of power, so that it may become something to be fought for by the satrias. Wahyu stories are generally grouped in carangan $^{x}$ plays. Citing Feinstein, Darmoko (1988) reports that there are 22 wahyu stories between 106 carangan plays (p. 6). A satria may get a wahyu by "seeking it through 'laku $u^{\text {'xi }}$ in the form of mandatory abstinence, asceticism and 'lelana brata' (ascetic journey)" (p. 132). Of the six plays Darmoko discusses in his thesis, he finds that wahyu may take the forms of sukma (the soul of the wahyu seeker is summoned to meet gods) (p. 22), ajaran (the seeker gets a teaching from a god or brahman) (p. 29), and cahya (the seeker sees a beautiful/pearl like light) (p. 54). Unlike wahyu discussed by Darmoko, however, Ravana's wahyu is in the form of a vision of the coming of a goddess who would incarnate into a woman.

In Ki Sinarto's Ramayana, to become the king who can give prosperity to his people, Ravana is commanded by his grandfather, King Sumali, to do meditation in a cave called Gohkarna. It is expected that if he meditates properly, he will get a wahyu as the new king. This command seems to say that without getting a wahyu, Ravana does not have enough power or legitimacy to be a king. During Ravana's meditation, finally a wahyu of prosperity descends. The wahyu of prosperity is in the form of a goddess, who will be born to a Lankan baby girl. King Ravana would be successful if he stays with the incarnation of Goddess Vedavati, the prosperity goddess. Incidentally, at that time the wife of Ravana called Tari was pregnant. Ravana is sure that she would give birth to a baby girl and he promises to love the baby (Sinarto, 2006, Cass. 3-4).

From this point we can see that a woman can have a legitimizing power. This concept has developed both in the world of shadow puppet and the kingdoms of Java. We know that in the history of the kingdoms of Java, Ken Arok had to marry Ken Dedes, who was believed to be the incarnation of a wahyu of power/leadership. To get her, he even had to kill Tunggul Ametung, the husband of Ken Dedes. Some Javanese people still believe it to the present. For example, according to Sulastomo (2007), it happens in the case of former president Suharto.

In the Javanese philosophy which was believed by Soeharto, the position/power, especially the presidency, can only be obtained if somebody is blessed with a "wahyu". The wahyu does not necessarily need to be sent down to him, but it can be addressed to people close to him. In the case of Soeharto's presidency, the revelation was probably handed down to Mrs. Tien Suharto. Therefore, after the death of Madame Tien Soeharto he could no longer maintain his power (p. 6).

Therefore, we can see similarities among Ravana in the shadow puppet play, Ken Arok in the era of Javanese kingdoms in the past, and Suharto in the modern world. Women gain a central place as the recipient of wahyu, which means that they play an important role in the legitimizing of power. Thus, there are historical and philosophical relations among the three worlds. The relations between rulers and women are not just husband and wife or father and daughter, but also the ruler and the recipient of revelation. Ki Sinarto still reproduces such a meaning although he has a different interpretation of Ramayana. As the recipient of wahyu, Sita is the daughter of Ravana. This interpretation differs from the common one, as it is represented by Vibhishana's understanding, that as the incarnation of goddess of prosperity, Sita is another woman whom Ravana wants to take as a wife.

However, the relations between rulers and women in Ramayana by Ki Sinarto are not always positive. The discourse of women as barriers to men's career also surfaces. For instance, Ravana mentions the word 'wedokan', which is a pejorative for the word 'women', when criticizing Danaraja. To Ravana, Danaraja is worth criticizing since although a king who "angger ngocap mesthi kelakon, nduweni karep mesti bisa ketemu" [(whose) words are powerful, (and whose) wish must be satisfied] (Sinarto, 2006, Cass. 2) in getting women, he is ready to kill his own father for a woman. This shows that even a king can be blinded by a woman. Narada even mentions the word "gendhakan"xii (Cass. 3) which is also a stronger pejorative for the word 'woman', when advising Danaraja. Women are positioned as distractors to men's success, especially if they are attractive. To emphasize the fact, Ki Sinarto emphasizes Ravana's words and these words are repeated by the musicians and the audience: "Jagat iki tentrem dadi geger perkara we ... dok ... an" [This peaceful world becomes chaotic because of wo ... men (pej.)] (Cass. 3). These words are, of course, proceeded by a rowdy laughter. So, if in the case of wahyu women provide legitimacy to man, in the latter case women are teasers who can make men fail.

The connotation to the position of women in relation to rulers/leaders is also seen in Kaikeyi, the third wife of King Dasharatha of Ayodhya. Kaikeyi has the ambition to descend future kings, and when King Dasharatha proposes her to become his third wife, she is willing provided that if she gives birth to a son, her son should be crowned king. Being in love, King Dasharatha fulfills her request. From Kaikeyi, King Dasharatha eventually gets a son named Bharata, while from his first wife, Kausalya, he has already had a son named Rama. Forgetting his promise, King Dasharatha is about to crown Rama king of Ayodhya. Kaikeyi, of course, reminds King Dasharatha about his 
promise. As soon as he remembers his own promise to Kaikeyi, King Dasharatha gets downhearted. When king Dasharatha says that he does not have the heart to tell Rama about it, Kaikeyi firmly says that she will do it herself. Without hiding her feelings, she tells Rama that the throne of Ayodhya will be handed down to his brother Bharata, not himself. King Dasharatha cannot do anything about it, also when Rama finally retreats to Dandaka woods (Cass. 5-6).

In this sanggit, Kaikeyi is pictured as a woman who is so adamant with the promise given to her, and she threatens King Dasharatha that she will commit suicide if he does not keep his promise. Kaikeyi represents women who work behind the scenes, women who can influence her husband's decisions even when her husband is a king. This representation is not foreign in Javanese culture. According to Handayani and Novianto (2004), even though positioned as 'kanca wingking'xiii in the domestic domain, Javanese women have their own way to influence her husband in the public spheres. People often talk about this in the modern era in Tien Suharto, who allegedly was so influential on the decisions of the former President Suharto. Ki Sinarto reproduces this in the show, and Kaikeyi is an extreme representation of this fact. Ki Sinarto shows that in relations with women as such, men turn out to be 'powerless'. Looking tough in the outside, men turn out to be weak in their homes. According to Handayani and Novianto,

in reality in the Javanese culture and its concept of power, Javanese women who tend to be feminine can place themselves well and they are even able to influence public decisions ... it shows how Javanese women play a dominant role (read: to be in power) without jeopardizing Javanese cultural values" (pp. 26-27).

The Javanese cultural values that Handayani and Novianto mention, of course, are the patriarchal values which are supposed to place advantages to men. However, "there are no relations of power without any hindrance; ... . [Which] form a variety and can be integrated in global strategies " (Foucault, 2002, p. 176). Thus, the relations between men and women which on the surface look advantageous to men may be balanced by women's counter strategies. This provides proofs to the Foucauldian view of power in which power is by no means clearly structured in that those who are on top will always take the benefits. "Power relations in this case are not seen as linear and vertical ..." (Budianta, 2006, p. 7); instead, power is in fact dispersed to every sides and directions allowing every subject to play his/her roles.

\section{Power and the Family}

The Javanese shadow puppet world is the story of the nobility, that of the aristocracy. In fact, the main conflicts in Javanese shadow puppet stories, especially in the Mahabharata, is family disputes. We know that the central story of the Mahabharata is about the power struggles in the Bharata clan, between the children of Dhritarashtra who are called Kaurava and those of Pandu who are named Pandava. The Kaurava are led by Suyudana or Duryodhana and the Pandava are led by Puntadewa or Yudhistira. These disputes end with Bharatayudha, which literally means "the war of the Bharata." Ramayana, on the other hand, is more driven by women issues, namely the conflict between Rama and Ravana who fight over a woman called Sita. In Ki Sinarto's sanggit, however, the Ramayana deals with family disputes just like Mahabharata.

Ki Sinarto's (2006) sanggit begins with a father-son conflict between Vishrava and Danaraja who fight for Kaikesi, the Lanka's princess (Cass. 1-2). Knowing that Kaikesi has become his father's wife, Danaraja, who was respectful to his Brahman father, gets furious and speaks in a rough, impolite language.

DANARAJA: Tuwa tuwas mbrabas ora nglungguhi klawan tuwamu Begawan Wisrawa. Pager mangan tanduran keparat! Dudu karepe dhewe ngatase duweke anake malah dirangsang digaglak dhewe. Watak brahmana adoh klawan sipat kabrahmananти. Ya anakmu kang bakal nglunasi nyawamu dina samengko. (Cass. 2)

[DANARAJA: As an old man you don't deserve any respect, Vishrava. Betraying your own son, damn you! How come you have the heart to grab what belongs to your own son. You have lost your Brahman attitudes. I, your own son, will finish you at this moment. (Cass. 2)

Danaraja has lost his respect to Vishrava because, in his opinion, Vishrava has double crossed him. He never suspected that his father would take Kaikesi for himself. Therefore, the father-son relationship is disconnected, and Danaraja uses his power as a king to punish his father. In the hands of Danaraja, power can be used to punish his own father when his father hurts him.

The presence of Dhasamuka/Ravana to defend his father makes the family problem complicated since the war extends to that between half-brothers as well. Ravana dares to challenge Danaraja since, besides attacking his father, Danaraja has also attacked his country, Lanka. When asked by Danaraja if he dares to fight his own elder brother, Ravana says: "Dulur [ya] dulur, ning nek perkara negara bakal tak belani" (Cass. 3) [I will defend my country even though I have to fight against my sibling] (Cass. 3). A battle between step brothers finally explodes. Ravana is almost killed if not for the presence of God Narada who stops the battle. To avoid further animosity, God Narada should put them apart by taking Danaraja to heaven. In doing so, God Narada says, “. . . sliramu urip . . . ana ing madyapada tan wurunga besuk sliramu bakal wales winales klawan si Dasamuka. . ." [ . . if you live . . in the earth you will fight again and again with Dhasamuka ... .] (Cass. 3). Therefore, Danaraja should be taken away. It implies that a family dispute which ends up with state rivalries will continue to happen unless one of them dies or 'is removed' from the world.

The family dispute, however, develops to a different direction when Vibhishana, younger brother of Ravana, throws Ravana's baby daughter-Sita-away. When finally a war to win Sita happens between Lanka led by Ravana and Pancavati led by Rama, Vibhishana decides to 
take Rama's side. Unlike the conventional plot of Ramayana, Ki Sinarto makes the war a family dispute, between step father and step son as well as among brothers. The war is a misunderstanding which should not take place if Rama, as the incarnation of Vishnu, really knew the heart of the matter. The misunderstanding stems from Vibhishana who, to Ravana, has done a "kudeta halus" [silent coup] to his authority (Cass. 7). Ravana blames Vibhishana for planning to take his power by taking side on the possible winner. The interpretation is against the narrative convention since usually Vibhishana belongs to the right side by being a satria who chooses to take side with others rather than to defend an evil family member.

It is safe to state that shadow puppet performances influence and, at the same time, are influenced by conflicts of power in Java. From the text it is seen that to the Javanese elites, power is more important than the family; and however close a family relation among them may be, they would be ready to destroy one another for the sake of power.

\section{Power and the People}

Power in terms of leadership either in the context of a modern state or a kingdom is connected with leader-people relationships. In the concept of the Javanese kingdoms, the state belongs to the king and the people (kawula), who are subjects to the king's power. At least in its 'imagined' conception, the king who is usually considered as the incarnation of a god becomes the benevolent provider for of the welfare of the people. This kind of imagined relationship can also be seen in Ki Sinarto's Ramayana. When he decides to descend from his power (in Javanese it is commonly called lengser keprabon ${ }^{x i v}$ ), while handing the throne to Ravana his grandson, King Sumali tells him that "Praja Ngalengka Diraja didekna kuwi kanggo katentreman lan kamulyaning para kawula" [The kingdom of Lanka was established for the welfare of the people] (Cass. 3). Therefore, he expects that Ravana should be able to complete this mission. To do so, Ravana should prepare himself by experiencing 'tapa brata ${ }^{x v}$ to get wahyu (revelation). King Sumali states that he has been such a king to his people:

Eyang ora nate mulasara lan ora nate kumawasa nguwasani praja Ngalengka Diraja. Luhur-luhuring panguwasa iku yen gelem mbudidaya kamakmuraning para kawula ning ora kanggo diri priyangga utawa pribadi (Cass 3).

[I have never oppressed (my people) and neither do I rule ruthlessly. The best ruler is he who pursues prosperity for his people instead of for himself] (Cass $3)$.

Ki Sinarto's use of the term 'panguwasa' instead of 'ratu/king' gives way to a broader interpretation, not only about the power of a king but also that of any power position which the audience may associate it with, especially, governmental or political positions. King Sumali further says, "Tanpa guna ngger nadyan nikmat uripmu .. . ning yen kekeset ana ing mustakaning kawulamu kabeh" [It is meaningless if you prosper ... by oppressing ${ }^{\mathrm{xvi}}$ your people (Cass. 3). As a ruler, therefore, Ravana should not be self- centered.

Such a teaching, of course, is common in a Javanese shadow puppet performance. This kind of teaching makes critics think that shadow puppet is full of good values about leadership, values that should be implemented even in today's context. However, even though such values are reproduced times and again, Javanese people are never really free from the exploitation of those in power. When there are disputes among the powerful, they even become the victimized subjects. It shows that there is a gap between the prosperous society imagined by the ruling class and everyday reality experienced by the people. It may also be considered that there is no significant difference between the past, when Java was ruled by the aristocracy and the present when Java becomes a part of a modern nation called Indonesia.

What is peculiar about the teachings in wayang kulit is, since the story is about kingdoms, people 'belong' to the king. When this teaching is related to the present context, the king-people relations in a monarchial system cannot be directly implemented to president-people relations in a democratic system. Therefore, Javanese people have difficulties in seeing leaders as 'servants' of the people (servant leadership). During the New Order (1965-1998), the government introduced the concept of 'abdi negara' (the state servants) for state officials. This concept is a far cry from the idea of servant leadership since, instead of serving the people, the government officials served those higher than themselves and eventually they all served the president who was treated as a king.

It is true that, in Javanese shadow puppet, people are represented by the Panakawan who are considered to have god-like wisdoms. Semar, for instance, is characterized as a half-god servant since he is God Ismaya who becomes human. Semar is the source of wisdom for the satrias of Amarta. In Ki Sinarto's Ramayana, Ravana's panakawan, Togog, also gives advice to his master. For example, when Ravana is about to punish Vibhishana, Togog advices, "Nglungguhi wataking ratu, ora mung saget momong praja ning kudu bisa momong kluwarga" [A king should not only be able to babysit ${ }^{x v i i}$ the country, but also his family] (Cass. 4). This use of the word 'momong'[babysit] the kingdom (or country in its present context) means taking care of the country the way parents, or even baby sitters, do to children. The people, therefore, are babysat by the king and his officials in the shadow puppet world, and they are babysat by the president and the government officials in the present context. Thus, it is clear who exercises the domination.

The Panakawan are sometimes used by the dalang to criticize those in power. For example Ki Sinarto criticizes East Java government officials who chose to engage in Surakarta style shadow puppet instead of East Javanese. Through Panakawan Petruk he says,

Angger tung ning ngendi kok mesti teka kana. Rumangsaku sing mbayar pajek ki ya wong Jawa Timur tapi rejekine kok ya mesti diemplok wong kana . . Ngono kok wong Jawa Timur kongkon makmur masyarakate ka ngendi?... (Cass. 4) 
[Every time we hear a show, it must be from there [Central Java]. The tax payers are the people of East Java, but the money goes to them ${ }^{\text {xiiii }}$.... . How can they expect East Java people to be prosperous? . . . ] (Cass. 4)

This statement is Ki Sinarto's criticism to East Java government officials who do not care about East Java (shadow puppet) artists. Shadow puppet shows in government offices are usually done by artists from Central Java since government officials prefer Surakarta style which is considered to be more refined. This preference, to $\mathrm{Ki}$ Sinarto, makes East Java artists unable to survive. Even though Ki Sinarto is a government official himself, he has the courage to criticize the government through the Panakawan. In other performances, however, the Panakawan who represent the people are used for the government propaganda. The best example for this use is a clip from "Semar Boyong" by Ki Anom Suroto, which Basuki has quoted a number of times in his papers:

PETRUK: Granpa Only has three children: 1. Garen, 2. Petruk, 3 Bagong. Plus ABRI (the military) and Pegawai Negeri (government officials). Let's three of us unite. We need not show numbers now, we need to do it only when there is general election. Gareng, me, and bagong, are one place, one language, one nation, and one country. (We) don't need to quarrel. Let's help grandpa because he is now having the will to develop the country. The development can work well if we are one in 'cipta,' 'rasa,' 'karsa' to work together. We, young people, have heavy tasks. Our father's job was to free the nation. Our job is to 'fill out' the freedom. Let's not fill the freedom out with quarrels, what would be the benefits of quarrels? In a battle both the winner and the loser suffer.

BAGONG: But please. The one who is big and tall is only you, please protect your brothers. (as cited in Basuki, 2006, p. 84)

We see in this quotation that panakawan become the mouth piece of the ruling group, asking the people to cooperate with the government and avoid conflicts. The audience was clearly aware that Petruk represented the ruling party at that time (Golkar) while Gareng and Bagong represented one of the other two small parties (PPP and PDI). They were also clearly aware that Semar, the father, represented the president who was in full power at that moment.

It may be argued, therefore, that a dalang (a puppeteer) is an artist that is continuously subject to power relations. Whatever he presents in a performance is dependent upon the power relations between a dalang and those who invite him to perform.

The relations, however, is not necessarily linear since in the case of Ki Sinarto, who is a government official, a dalang may criticize those in power; while in the case of Ki Anom Suroto, who is not a government official, a dalang becomes the mouth piece of those in power.

However, the context of the performance also determines the relations. In terms of time, for instance, it is difficult to predict if Ki Sinarto would have criticized the government if he did the performance in the New Order time (1965-1998). Likewise, it is safe to doubt that Ki Anom Suroto is now still the mouth piece of the present establishment.

\section{CONCLUSION}

The dominant meanings that are (re)produced in $\mathrm{Ki}$ Sinarto's 'Ramayana' are that of power. The issue of power, in fact, is one of the issues that are always reproduced in shadow puppet performances. The Javanese people have their own concepts of power, and the concepts develop in line with the progress of Javanese power relations. In Foucauldian term, the meanings of power are always related to other issues, and in this text the meanings of power are related with the issues of the state, revelation, women, family, and people. These meanings are continuously (re)produced and circulated especially when Javanese socio-political condition in some kind of tension. $\mathrm{Ki}$ Sinarto is a part of the (re)production and circulation of those meanings of power, and he acquires knowledge related to power both from the world of shadow puppet and from his socio-political contexts.

Shadow puppet, as a cultural product, is like other cultural products such as prisons or hospitals. It reminds us, therefore, of Foucault's discussion of both of these in Dicipline and Punish (1977). Foucault discusses, among other things, how the concepts of "prison" and "criminals" are ever-processing and constantly changing based on power relations among subjects: prisoners, wardens, the police, legal officials, even psychologists. Shadow puppet also has a long history as the prison or school. Therefore, "wayang kulit" and "dalang" are subject to relations of power-knowledge like "school" and "teacher" or "prison" and "criminal." If the power relations in the context of "prison" and "criminal" are not necessarily negative, except that there is a kind of domination on "who are not normal" by "those who are normal," let alone cultural products such as "wayang kulit" and "dalang". As a work of art, people may not see "wayang kulit" as a site of power relations. In fact, with its position as an art that is supposed to be a means of cultural as well as social education, power is ever-present in shadow puppet theatre.

\section{REFERENCES}

Anderson, B. (1990). Kuasa-kata: Jelajah budaya-budaya politik di Indonesia. R.B. Santosa (Trans.). Yogyakarta: Mata Bangsa.

Basuki, R. (2006). Panakawan's discourse of power in Javanese shadow puppet during the new order regime: From traditional perspective to new historicism. $K @ t a$ Journal, 8(1), 68-87.

Budianta, M. (2006). Budaya, sejarah, dan pasar: New historicism dalam perkembangan kritik sastra. Susastra, 2(3).

Darmoko (1988). Wahyu dalam lakon wayang kulit purwa: Telaah intrinsik (Unpublished thesis). Depok: FS-UI.

Ensiklopedi Wayang Purwa (1991). Jakarta: Balai Pustaka. Foucault, M. (1977). Discipline and punish. London: Penguin. 
Foucault, M. (2002). Power/knowledge: Wacana kuasa/ pengetahuan. Y. Santosa (Trans.). Yogyakarta: Bentang Budaya.

Handayani, C.S., \& Novianto, A. (2004). Kuasa wanita Jawa. Yogyakarta: LKiS.

Kayam, U. (2001). Kelir tanpa batas. Jogjakarta: Gama Media.
Moedjanto, G. (1987). Konsep kekuasaan Jawa: Penerapannya oleh raja-raja Mataram. Yogyakarta: Kanisius.

Sinarto, K. (2006). Ramayana [Cassettes 1-7]. Wonocolo: Surabaya.

Sulastomo (2007, April 25). Antara Bung Karno dan Pak Harto. Kompas, p. 6.

\section{Note:}

'Suffix - an means "belong to the area of'. Malangan sub-style means a sub-style that belongs to the area/district of Malang

${ }^{i i}$ Mataraman style, which consists of Surakarta and Yogyakarta styles, is the major style in Javanese Shadow Puppet.

iii There are several tlatah (cultural area) in East Java. Tlatah Mataraman is located in the western part of the province closely connected with central Java province where the Javanese kingdoms are. Tlatah Arek lies to the east of tlatah Mataraman, ranging from county of Lamongan to the city of Surabaya in the north and the county of Malang in the south.

${ }^{\text {iv }}$ The change of acts in Javanese shadow puppet is indicated by the change of pathets in the gamelan music. The change of pathets is like the change of keys in western music.

${ }^{\mathrm{v}}$ The opening scene in an act. It serves as an exposition.

${ }^{v i} \mathrm{Ki}$ Sinarto was born in Lamongan county, got an education from Sekolah menengah Kesenian Indonesia (Secondary Art School) in Surabaya majoring in Javanese shadow puppetry, and finished his Bachelor degree in Karawitan (gamelan music) at an art college in Surabaya. Besides being a puppeteer, Ki Sinarto is now working in Taman Budaya Jawa Timur (East Java Cultural Park), a state-owned cultural institution.

vii Audience refers the subjects who are present at the performance, while intended audience refers to those who are not present but are addressed by the performance.

viii The nobility.

ix This discussion is also related to the topic of power and family which will be discussed later.

${ }^{x}$ Stories created outside the historical canon.

${ }^{x i}$ A kind of spiritual journey.

xii 'Gendakan' is usually related to a kind of 'forbidden relationship', either between singles or married people.

xiii Literally means 'rear friend' with the word 'rear' alluded to 'kitchen'.

${ }^{\text {xiv }}$ This concept became famous in the end of New Order regime (1998) when it was related to President Suharto's will to step down peacefully, which he finally failed to achieve.

${ }^{\mathrm{xv}}$ An act of asceticism by going to secluded places like the mountains or forests.

xvi The word "keset" literally means "mat", on which people usually step and wipe dirt on their shoes. "Kekeset" is the action of doing so.

xvii 'Babysit' is a direct translation of the word 'momong'. A subtler translation may use the word 'take care', but it would not really carry the meaning the dalang is trying to say.

xviii The literal translation of 'diemplok wong kana' is 'eaten up by people from there'. It is a sarcastic expression that shows how tax payers' money goes to other people. 